\title{
GAMBARAN HISTOPATOLOGIK LAMBUNG TIKUS WISTAR SETELAH DIINDUKSI DENGAN ASPIRIN
}

\author{
Poppy M. Lintong \\ Lily L. Loho \\ Herman Anggran
}

\author{
Bagian Patologi Anatomi Fakultas Kedokteran Universitas Sam Ratulangi Manado \\ Email: magda_plin@yahoo.com
}

\begin{abstract}
Aspirin is one of the non-steroid-anti-inflammatory drugs. Its pharmacodynamic effects are as an analgesic, antipyretic, anti-inflammatory, anti-thrombotic, and uricosuric agent. The side effects of aspirin are on the respiratory tract, the gastrointestinal tract, blood, metabolic processes, endocrine functions, pregnancy, hypersensitivity, and drug interaction. The purpose of this study was to evaluate the macroscopic and microscopic features of wistar rat stomachs after the administration of aspirin. This was an experimental study, using nine wistar rats divided into three groups equally. Group I, the control group, was given a food pellet only. Group II was given the pellet, added with aspirin $21 \mathrm{mg}$ daily for 10 days. Group I and Group II were terminated on day 11. Group III was given the pellet, added with aspirin 21 $\mathrm{mg}$ /day for 10 days, and was terminated on day 14. All the wistar rat stomachs were examined macroscopically and microscopically. The results showed that the control group had a macroscopically normal stomach architecture, and the mucosa layers and rugae were intact and looked pinkish white. The groups treated with aspirin still showed normal stomach architecture, and the mucosa layers and rugae were intact but looked more palid than that of the control group. Microscopically, the stomach walls of the control group were normal, but groups treated with aspirin for 10 days revealed edema of the lamina propria, dilatation of capillaries; and predominantly neutrophilic infiltration in the lamina propria. Ceasing of aspirin administration showed a resolution of the inflammatory process, marked by diminished infiltration of PMN cells and tisuue edema. Conclusion: Aspirin treatment of 21 $\mathrm{mg}$ a day for 10 days revealed histopathologically acute gastritis of the wistar rat stomach walls. The inflammatory reaction was diminished after the cessation of aspirin.
\end{abstract}

Keywords: aspirin, histopathology, stomach.

\begin{abstract}
Abstrak: Aspirin tergolong obat anti-inflamasi non-steroid (AINS) yang secara farmakodinamika mempunyai efek analgesik, anti-piretik, anti-inflamasi, anti-trombotik, dan urikosurik, namun mempunyai efek samping pada saluran cerna terutama lambung. Penelitian ini bertujuan untuk mendapatkan gambaran histopatologik (makroskopik dan mikroskopik) lambung tikus Wistar setelah pemberian aspirin. Penelitian ini bersifat eksperimental dengan menggunakan sampel sembilan ekor tikus Wistar yang dibagi atas tiga kelompok. Kelompok I (kontrol) terdiri dari tiga ekor tikus yang diberi pelet biasa dan air minum. Kelompok II terdiri dari tiga ekor tikus yang diberi pelet biasa, air minum, dan aspirin dosis $21 \mathrm{mg} /$ hari selama 10 hari. Pada hari ke-11 kelompok I dan II diterminasi. Kelompok III terdiri dari tiga ekor tikus yang diberikan pelet biasa, air minum, dan aspirin dosis $21 \mathrm{mg} /$ hari selama 10 hari, kemudian aspirin dihentikan dan tikus diterminasi pada hari ke-14. Setelah diterminasi, kelompok I-III diotopsi, diambil organ lambungnya, kemudian dilakukan pemeriksaan histopatologik. Hasil penelitian memperlihatkan makroskopik mukosa lambung tampak lebih pucat sedangkan mikroskopik menunjukkan tanda-tanda radang akut. Penghentian pemberian aspirin diikuti dengan resolusi reaksi inflamasi yang ditandai oleh penurunan infiltrasi sel-sel radang PMN dan edema jaringan. Sinpulan: Pemberian aspirin $21 \mathrm{mg} /$ hari selama 10 hari mengakibatkan
\end{abstract}


terjadinya gambaran histopatologik gastritis akut pada lambung tikus Wistar. Reaksi inflamasi menurun setelah penghentian pemberian aspirin.

Kata kunci: aspirin, histopatologi, lambung.

Aspirin tergolong obat anti-inflamasi nonsteroid (AINS) yang banyak dikonsumsi masyarakat untuk mengobati penyakit rematik. ${ }^{1-3}$ Selain sebagai anti-inflamasi, aspirin merupakan agen anti-trombotik yang banyak dipergunakan pada penyakit jantung koroner (PJK) untuk mencegah terjadinya agregasi trombosit. ${ }^{4}$ Penggunaan aspirin lebih sering ditujukan untuk mengatasi rasa nyeri, meskipun aspirin juga merupakan antipiretik yang efektif. ${ }^{1}$ Food Drugs Administration (FDA) telah menyetujui penggunaan aspirin dosis $325 \mathrm{mg} / \mathrm{hari}$ untuk pencegahan primer pada infark miokard dan menganjurkan agar penggunaan obat ini dilakukan secara hati-hati oleh masyarakat umum. Obat ini sebaiknya digunakan bila telah diresepkan oleh dokter, dan dipakai sebagai tambahan untuk mengurangi risiko kejadian vaskuler sekunder antara lain infark miokard akut (IMA). ${ }^{4}$

Efek samping aspirin dosis biasa dapat menyebabkan gangguan lambung. Dosis rata-rata sebagai anti inflamasi 3,2-4 $\mathrm{g}$ setiap hari, sedangkan pada anak-anak 50$75 \mathrm{mg} / \mathrm{kg} \mathrm{BB} / \mathrm{hari}$. Efek samping aspirin dapat dikurangi dengan menelan aspirin bersama dengan makanan diikuti segelas air atau antasida. ${ }^{1}$ Gangguan lambung yang dapat terjadi akibat aspirin ialah gastritis dan gastropati. ${ }^{5-7}$ Studi eksperimental dan epidemiologik telah membuktikan adanya peningkatan kejadian ulkus lambung pada pasien yang memakai aspirin dosis tinggi. ${ }^{8}$ Gastritis yang terjadi akibat aspirin disebabkan karena iritasi mukosa lambung oleh tablet aspirin yang tidak larut dengan sempurna, penyerapan oleh lambung, atau adanya hambatan produksi prostaglandin. ${ }^{1}$

\section{ANTI-INFLAMASI NON-STEROID (AINS)}

Obat-obat anti-inflamasi non-steroid (AINS; NSAIDs, nonsteroidal anti-inflammatory drugs) terdiri dari beberapa golongan obat yang heterogen secara kimia tetapi obat-obat ini mempunyai banyak persamaan dalam efek pengobatan dan efek samping yang ditimbulkannya. ${ }^{1-3}$ AINS digolongkan atas dua golongan besar yaitu golongan asam karboksilat dan asam enolat. Asam karboksilat terdiri dari asam asetat, derivat asam salisilat, derivat asam propianat, dan derivat asam mefenamat. Asam enolat terdiri dari derivat pirazolon dan derivat oksikam. Aspirin tergolong derivat asam salisilat. ${ }^{3}$

Pemakaian aspirin jangka panjang sering ditemukan pada masyarakat karena obat ini mudah diperoleh tanpa menggunakan resep. Aspirin tergolong salisilat yang terpenting dan menjadi populer pada tahun 1899 ketika sifat anti-inflamasinya diperkenalkan. ${ }^{1}$ Aspirin (asetosal, acetylsalicylic acid, ASA) merupakan obat antiinflamasi yang efektif, lebih efektif sebagai analgesia, dan cepat diserap oleh mukosa lambung dan usus halus bagian atas. Golongan ini mempunyai waktu paruh 15 menit dan dihidrolisis dengan cepat menjadi asam asetik dan salisilat oleh esterase dalam darah dan jaringan. Salisilat dalam darah berikatan dengan albumin dan ikatannya dapat menjadi jenuh, sedangkan bagian yang tidak berikatan dapat bertambah jika konsentrasi obat bertambah. Salisilat menjadi jenuh bila dosis obat lebih dari $600 \mathrm{mg}$, sehingga penambahan dosis akan meningkatkan konsentrasi salisilat yang tidak berimbang. Bilamana dosis aspirin meningkat, waktu paruh eliminasi salisilat meningkat dari 3-5 jam (untuk dosis $600 \mathrm{mg} /$ hari) menjadi 12-16 jam (untuk dosis lebih besar dari 3,6 gr/hari). Alkalinisasi urin meningkatkan laju pengeluaran salisilat bebas dan konyugatnya yang larut dalam air., ${ }^{1,2}$

Secara farmakodinamika aspirin mempunyai efek analgesik, antipiretik, anti inflamasi, anti platelet, dan efek urikosurik. Efek analgesik disebabkan oleh aksi pada bagian sistim saraf pusat, mungkin pada 
bagian hipotalamus. Pada dosis toksik aspirin menimbulkan gejala sakit kepala. Dosis analgesik bervariasi antara 300-1000 $\mathrm{mg}$ dalam 3-4 kali pemberian/hari. ${ }^{2}$ Efek antipiretik dapat menurunkan suhu tubuh pada penderita demam melalui kerjanya pada daerah termoreseptor hipotalamus dan pusat pengatur suhu. Penurunan suhu tubuh pada penderita demam disebabkan karena efek sekunder vasodilatasi dari aspirin terutama di daerah kulit dan bertambahnya pengeluaran keringat. ${ }^{1,2}$

Efek anti-inflamasi aspirin sebagai penghambat non-selektif kedua isoform cyclo-oxygenase (COX). Salisilat jauh lebih kurang efektif dalam menghambat kedua isoform dibandingkan golongan COX lainnya. ${ }^{1}$ Salisilat dosis besar (5-8 g/hari) digunakan untuk pengobatan penyakit reumatik dan inflamasi lainnya. Peningkatan permeabilitas kapiler selama proses radang atau inflamasi dikurangi oleh salisilat yang mencegah pembentukan edema, eksudasi seluler, dan nyeri. Kemampuan untuk menghambat respons imun seluler tampaknya menyokong efek terapeutiknya. ${ }^{2}$ Efek anti-agregasi trombosit dari aspirin digunakan untuk mencegah trombosis. Aspirin dosis rendah kira-kira $80 \mathrm{mg}$ sehari menyebabkan sedikit perpanjangan waktu perdarahan dan efek ini menjadi dua kali lebih besar bila pemberiannya dilanjutkan selama seminggu. Hal ini disebabkan efek karena penghambatan trombosit oleh COX bersifat ireversibel; oleh karena itu efek antitrombotik dari aspirin berlangsung 8-10 hari (sesuai usia trombosit). ${ }^{1,4}$

Efek-efek samping aspirin mencakup saluran napas, saluran cerna, darah, proses metabolik, fungsi endokrin, kehamilan, hipersensitivitas, dan interaksi obat. ${ }^{2}$ Efek samping aspirin pada saluran cerna yang tersering ialah nyeri epigastrium, mual, muntah, dan hampir selalu ada perdarahan mikroskopik. Kekambuhan gejala ulkus peptikum dan perdarahan saluran cerna dapat terjadi pada pasien yang menggunakan salisilat jangka panjang. Pasien dengan nyeri epigastrium akibat gastritis yang disebabkan oleh alkohol tidak boleh diberikan salisilat karena risiko terjadi perdarahan saluran cerna lebih besar. ${ }^{2}$ Semua obat antiinflamasi termasuk aspirin berpotensi besar menyebabkan kerusakan pada saluran cerna. Obat-obat dengan keasaman rendah seperti salisilat dapat masuk ke dalam sel dengan konsentrasi tinggi karena pada $\mathrm{pH}$ intrasel bentuk ionisasi obat lebih banyak dan tidak dapat segera didifusikan keluar dari dalam sel. Kadar salisilat intrasel yang tinggi menyokong terjadinya erosi mukosa lambung. Penghambatan sintesis prostaglandin oleh salisilat turut menyokong terjadinya kerusakan epitel mukosa saluran cerna. Prostaglandin terutama $\mathrm{PGI}_{2}$ dan $\mathrm{PGE}_{2}$, berfungsi sebagai penyekat pada mukosa lambung dengan cara meningkatkan aliran darah serta pembentukan mukus dan sodium bikarbonat sehingga mengurangi pelepasan $\mathrm{HCl}$ dan enzim-enzim pencernaan). ${ }^{1-3}$

Nyeri epigastrium, mual dan muntah yang ditimbulkan oleh konsumsi obat aspirin menunjukkan adanya radang pada lambung (gastritis akut). Pada kasus-kasus berat gastritis akut dapat menjadi gastritis erosif, ulserasi yang disertai perdarahan, hematemesis, melena, atau perdarahan hebat. $^{8}$

Gastritis yang disebabkan karena obat disebut gastritis diinduksi obat, ${ }^{5}$ (chemical gastritis, ${ }^{6}$ chemical/reactive gastropathy $\left.{ }^{7,9}\right)$. Keadaan gastritis yang berlangsung lama oleh obat-obat anti inflamasi dapat juga menyebabkan gastritis hemoragik; ${ }^{9}$ bila terjadi akut disebut acute errosive gastropathy. ${ }^{10}$ Selain disebabkan oleh obat, gastritis juga dapat disebabkan oleh hal-hal lain seperti uremia, iskemia, syok, bahan korosif, radiasi, makanan tertentu, sepsis, trauma, infeksi tertentu, alkoholisme, dan luka bakar hebat. ${ }^{5}$

\section{Gambaran histopatologik gastritis yang diinduksi obat/kemikal (gastropati reaktif)}

Gambaran makroskopik lambung pada pasien dengan pemakaian aspirin jangka panjang dapat memperlihatkan mukosa lambung normal, kongestif, erosi, atau ulserasi.

Pemakaian obat-obat anti inflamasi seperti aspirin ataupun bahan kimia jangka 
panjang dapat menyebabkan perubahanperubahan mikroskopik mukosa lambung. Gambaran mikroskopik klasik pada gastropati reaktif ialah hiperemia dan edema mukosa lambung, erosi superfisial, hiperplasia foveolar, dan perubahan-perubahan regeneratif. ${ }^{7}$ Walaupun jarang dilakukan, biopsi endoskopik dapat memperlihatkan hiperplasia foveolar, edema, hiperemia, perdarahan segar fokal, nekrosis fokal pada sel-sel foveolar dan permukaan mukosa. ${ }^{10}$ Gambaran gastritis akut juga dapat terlihat pada pemakaian obat AINS. Secara histologik, gastritis akut kadang sulit diidentifikasi sebab edema dan kongesti pembuluh darah lamina propria hanya ringan. Permukaan epitel tetap utuh meskipun terdapat sel-sel radang polimorfonuklear (PMN) tersebar di antara sel-sel epitel, atau dalam kelenjar-kelenjar mukosa. ${ }^{8}$

\section{Patogenesis gastropati reaktif/kemikal}

Perubahan histopatologik gastropati kemikal tidak memperlihatkan gambaran yang khas. Melalui endoskopi dan pemeriksaan histopatologik dapat dilihat perubahan dari gastropati kemikal, adanya gejala refluks alkalin pasca gastrektomi parsial, dan refluks empedu duodenogastrik sebagai tanda dari sindrom dismotilitas dan pemakaian AINS. $^{7}$

Pasien dengan refluks alkalin pasca gastrektomi ditandai oleh nyeri seperti rasa terbakar di daerah tengah epigastrium yang tidak berespon terhadap pemberian antasida, dan menjadi lebih parah bila makan atau berbaring. Muntah, anemia, dan penurunan berat badan dapat terjadi. Refluks empedu dapat dikonfirmasi dengan pemeriksaan endoskopi dan tanda-tanda patologik yang menyokong diagnosis, dan dikoreksi dengan pembedahan. Refluks empedu duodenogastrik sekunder terhadap dismotilitas gastroduodenal jarang ditemukan pada pasien yang tidak dioperasi. ${ }^{7}$

Pemakaian AINS yang sering dapat menyebabkan timbulnya gejala nyeri lambung. Sekitar $10 \%$ kasus nyeri lambung per tahun akan berkembang menjadi gastritis erosif atau ulserasi, dan 1-2\% kasus per tahun akan mengalami perdarahan lambung yang episodik. Gastropati reaktif umunya terjadi $10-45 \%$ pada pemakai NSAIDs jangka panjang, tetapi tidak terdapat hubungan antara gambaran mukosa dan gejala dispepsia. $^{7}$

\section{Mekanisme cedera}

Refluks duodenogastrik (disertai sekresi alkalin pankreatikoduodenal seperti asam, garam empedu, dan lycolecithin) menyebabkan gangguan pada penyekat mukosa lambung dan merusak epitel permukaan secara langsung. Hilangnya penyekat mukosa menyebabkan difusi balik ion hidrogen yang mengakibatkan cedera sekunder. Cedera permukaan mukosa lambung menyebabkan terjadinya pelepasan sel-sel epitel permukaan dan respons pembuluh darah berupa peningkatan permeabilitas dan pelepasan mediator histamin yang menimbulkan edema dan hiperemi mukosa lambung. Cedera berulang dapat menyebabkan pelepasan agen proinflamasi seperti platelet derived growth factor $(P D G F)$, yang merangsang proliferasi otot polos dan fibroblas pada lapisan muskularis mukosa yang meluas sampai ke lapisan mukosa. Cedera sel epitel terjadi setelah mukosa lambung terpapar dengan AINS oleh karena berkurangnya sintesis prostaglandin yang berperan penting sebagai sitoprotektif mukosa lambung. Selain itu, prostaglandin berefek mempertahankan aliran darah mukosa melalui peningkatan sekresi mukus dan ion bikarbonat, serta meningkatkan pertahanan sel-sel epitel terhadap cedera sitotoksik. AINS menginduksi terjadinya cedera mukosa lambung; sebagian dapat dicegah dengan pemberian analog prostaglandin (seperti misoprostol) dan menekan sekresi asam lambung dengan pemberian proton pump inhibitors (PPIs). Inhibitor COX-2 (AINS generasi kedua atau AINS selektif) telah dilaporkan dapat ditoleransi lebih baik oleh mukosa lambung, ${ }^{7}$

Cedera mukosa lambung dapat terjadi akibat pemakaian aspirin dalam waktu pendek (akut) atau menahun (kronik). Beberapa jam setelah aspirin dikonsumsi sudah dapat terjadi perdarahan subepitelial, 
sedangkan pemakaian teratur lebih dari 24 jam dapat menyebabkan gastritis erosif. Pemakaian aspirin jangka panjang mengakibatkan cedera mukosa yang lebih kurang dibandingkan dengan pemakaian akut, karena mukosa lambung telah beradaptasi dan menjadi lebih resisten terhadap aspirin. Respons adaptif juga dapat mencakup terjadinya penurunan infiltrasi sel-sel radang netrofil dan proliferasi epitel yang luas. Aspirin menginduksi kerusakan mukosa lambung melalui efek toksiknya yang menurunkan pertahanan mukosa lambung. Secara fisikokimiawi aspirin diserap dengan cepat dan terakumulasi pada mukosa sehingga menyebabkan penyekat mukosa lambung rusak. Kandungan salisilat dalam aspirin akan tertahan pada sel epitel mukosa lambung, diperantarai oleh proses yang tergantung ATPase yang mengakibatkan peningkatan permeabilitas membran sel dan terjadinya pembengkakan sel serta kematian sel. ${ }^{5}$

\section{METODE PENELITIAN}

Penelitian ini dilakukan dengan menggunakan metode eksperimental laboratorik pada hewan coba tikus wistar. Penelitian ini dilaksanakan di Laboratorium Riset Biomedik dan Patologi Anatomi Fakultas
Kedokteran Unsrat Manado selama empat bulan, dengan menggunakan sembilan ekor tikus berusia 6-8 minggu, dan diberi makan seperti konsentrat makanan ayam dalam bentuk pelet.

Sembilan ekor tikus wistar dibagi atas tiga kelompok, masing-masing kelompok terdiri dari tiga ekor tikus. Kelompok I untuk kontrol negatif; kelompok II diberikan aspirin $150 \mathrm{mg} / \mathrm{kgBB}$ selama 10 hari; kelompok III diberikan aspirin 150 $\mathrm{mg} / \mathrm{kgBB}$ selama 10 hari. Kelompok I dan II diterminasi pada hari ke-11, sedangkan kelompok III pada hari ke14. Setelah terminasi, dilakukan pengamatan lambung tikus secara makroskopik dan mikroskopik. Aspirin yang digunakan ialah aspilet dengan kandungan asam asetil salisilat $80 \mathrm{mg}$.

\section{HASIL PENELITIAN}

\section{Gambaran makroskopik}

Pengamatan secara makroskopik kelompok I, II, dan III, meliputi warna, konsistensi, dan ukuran lambung (Tabel 1, Gambar 1). Pada kelompok kontrol mukosa lambung tampak lebih kemerahan, sedangkan rugae masih utuh. Pada tikus perlakuan yang diberikan aspirin rugae masih utuh tetapi warnanya lebih pucat.

Tabel 1. Pengamatan makroskopik lambung tikus Wistar.

\begin{tabular}{|c|c|c|c|c|}
\hline Perlakuan & Kelompok & Warna & Konsistensi & Ukuran (mm) \\
\hline \multirow{3}{*}{ Kontrol negatif } & I. 1 & putih kemerahan & lunak & $2 \times 1 \times 0,8$ \\
\hline & I. 2 & putih kemerahan & lunak & $2,1 \times 1,1 \times 0,8$ \\
\hline & I. 3 & putih kemerahan & lunak & $2,2 \times 1,3 \times 0,8$ \\
\hline \multirow{2}{*}{$\begin{array}{l}\text { Aspirin } 21 \mathrm{mg} / \mathrm{hari} \\
\text { selama } 10 \text { hari }\end{array}$} & II.1 & putih pucat & lunak & $2,3 \times 1,3 \times 0,9$ \\
\hline & II. 2 & putih pucat & lunak & $2,1 \times 1,0 \times 0,9$ \\
\hline Terminasi hari ke-11 & II.3 & putih pucat & lunak & $2,2 \times 1,3 \times 0,8$ \\
\hline \multirow{2}{*}{$\begin{array}{l}\text { Aspirin } 21 \mathrm{mg} / \text { hari } \\
\text { selama } 10 \text { hari }\end{array}$} & III.1 & putih pucat & lunak & $1,8 \times 1,5 \times 0,6$ \\
\hline & III.2 & putih pucat & lunak & $2,0 \times 1,2 \times 0,9$ \\
\hline Terminasi hari ke-14 & III.3 & putih pucat & lunak & $2,2 \times 1,3 \times 0.9 \mathrm{~g}$ \\
\hline
\end{tabular}




\section{Gambaran mikroskopik}

\section{Gambaran mikroskopik lambung tikus Wistar kelompok I}

Ketiga ekor tikus memperlihatkan dinding lambung dilapisi mukosa dengan selsel epitel permukaan selapis torak. Di bawah epitel tampak kelenjar-kelenjar mukosa, sel parietal, sel chief, dan sel neuroendokrin. Lapisan muskularis dan serosa masih utuh serta tidak terlihat sel-sel radang.

\section{Gambaran mikroskopik lambung tikus Wistar kelompok II:}

Ketiga ekor tikus memperlihatkan gambaran yang sama yaitu dinding lambung dilapisi mukosa dengan sel-sel epitel permukaan selapis torak, kelenjar-kelenjar mukosa masih utuh, lamina propria edema dan pembuluh darah kapiler melebar, serta terdapat infiltrasi sel-sel radang PMN pada mukosa dan submukosa lambung. Diagnosis histopatologik ialah suatu gastritis akut, yang disebut juga gastritis kemikal atau gastropati reaktif akibat aspirin (Gambar 2).

\section{Gambaran mikroskopik lambung tikus Wistar kelompok III:}

Ketiga ekor tikus memperlihatkan dinding lambung dilapisi mukosa dengan selsel epitel permukaan selapis torak, kelenjar-kelenjar mukosa utuh, lamina propria edema disertai infiltrasi sel-sel radang PMN pada mukosa dan submukosa lambung yang lebih kurang dibandingkan dengan tikus kelompok II. Diagnosis histopatologik masih menunjukkan gambaran gastritis akut meskipun infiltrasi sel-sel radang PMN sudah berkurang dibandingkan dengan kelompok II (Gambar 3).

\section{BAHASAN}

Cedera akut pada mukosa lambung dapat disebabkan oleh banyak faktor dan memberikan gambaran histopatologik yang berbeda-beda. ${ }^{5}$ Tujuan penelitian ini untuk melihat efek pemberian aspirin terhadap gambaran histopatologik lambung tikus wistar. Pada penelitian ini telah terbukti adanya perubahan makroskopik maupun

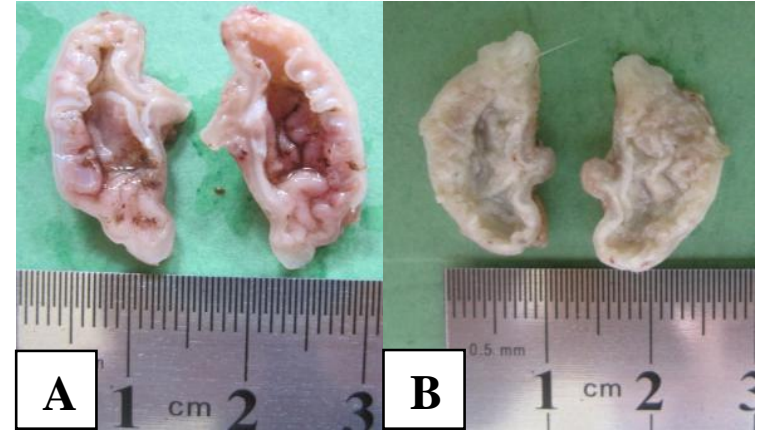

Gambar 1. Foto makroskopik lambung wistar yang dipotong memanjang. A, Kelompok kontrol. B, Kelompok dengan pemberian aspirin.

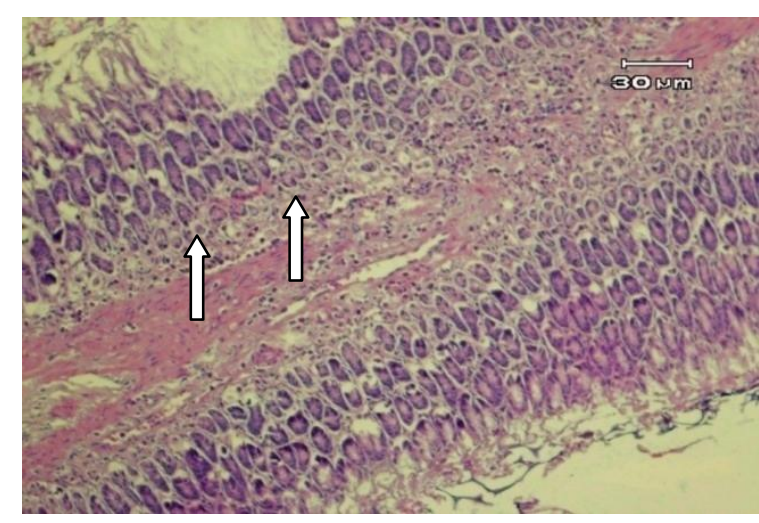

Gambar 2. Mikroskopik lambung wistar kelompok II dengan perlakuan pemberian aspirin $21 \mathrm{mg}$ selama 10 hari. Tampak infiltrasi sel radang PMN (anak panah) dan edema pada daerah lamina propria mukosa dan submukosa lambung, serta pelebaran pembuluh darah kapiler (pembesaran 200x).

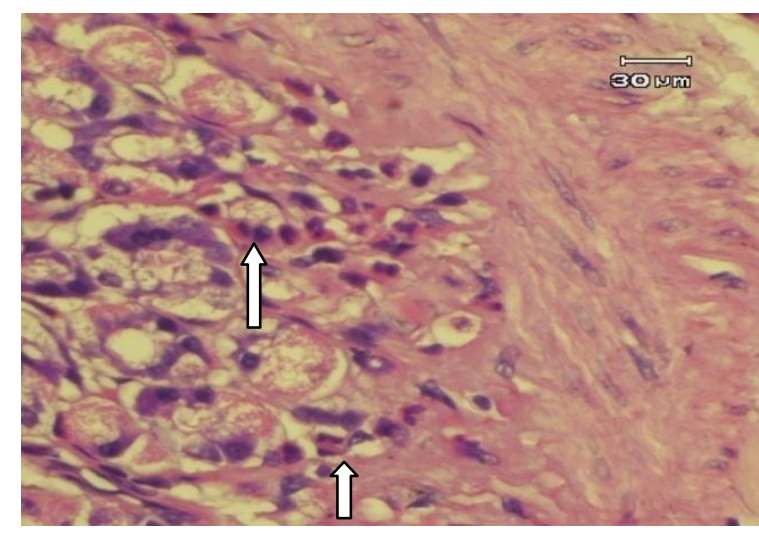

Gambar 3. Gambaran mikroskopik lambung wistar kelompok III. Pada daerah mukosa bagian bawah dan sebagian submukosa tampak sedikit sel radang PMN (panah) sedangkan struktur kelenjar masih baik (pembesaran $400 \mathrm{x}$ ). 
mikroskopik dari lambung tikus Wistar yang diberikan perlakuan aspirin dibandingkan tikus kontrol.

Secara makroskopik baik lambung tikus kontrol maupun yang diberi pelakuan aspirin tidak memperlihatkan perubahan arsitektur, rugae masih terlihat baik, tidak tampak ulserasi, namun lambung tikus yang diberikan aspirin tampak lebih pucat dibandingkan tikus kontrol. Terjadinya hal ini mungkin karena efek aspirin yang mengakibatkan cedera mukosa lambung dan mengganggu aliran darah mukosa karena penghambatan sintesis prostaglandin; ${ }^{5,7}$ hal ini dapat menyebabkan iskemia sehingga lambung terlihat lebih pucat.

Secara mikroskopik mukosa lambung tikus kontrol maupun tikus perlakuan masih ditutupi sel-sel epitel torak, tidak tampak erosi maupun ulserasi. Pada tikus perlakuan kelompok II (aspirin dosis 21 $\mathrm{mg} /$ hari selama 10 hari) mikroskopik menunjukkan gambaran gastritis akut tanpa erosi, ulserasi, maupun perdarahan, serta tanda-tanda gastritis akut seperti edema pada lamina propria, pelebaran pembuluh darah kapiler, dan banyak infiltrasi sel-sel radang PMN pada mukosa dan submukosa; hal ini sesuai dengan acuan pustaka. ${ }^{5-7,9}$ Dosis aspirin yang diberikan pada tikus perlakuan $21 \mathrm{mg} /$ hari yaitu sesuai dengan dosis $150 \mathrm{mg} / \mathrm{kgBB} /$ hari yang sudah melewati dosis terapeutik karena dosis aspirin sebagai antipiretik dan analgetik pada anakanak 50-75 mg/kgBB/hari. ${ }^{1-3}$ Konsumsi aspirin pada orang tertentu setelah beberapa jam dapat menimbulkan perdarahan subepitelial, dan bila lebih dari 24 jam dapat menyebabkan gastritis erosif. ${ }^{5}$ Pada penelitian ini telah terbukti bahwa aspirin dosis tinggi dapat menimbulkan cedera akut pada mukosa lambung. Pemberian aspirin selama 10 hari berturut-turut telah mengakibatkan cedera akut terhadap mukosa lambung dan memperlihatkan gambaran gastritis akut secara mikroskopik dalam gradasi ringan karena tidak disertai erosi dan ulserasi. Pada penelitian ini terlihat banyak sel-sel radang PMN tersebar dalam mukosa dan submukosa, edema, dan pembuluh darah kapiler melebar, tetapi sel-sel epitel permukaan tetap utuh dan tidak tampak erosi.

Aspirin dapat menimbulkan cedera mukosa lambung yang disebut sebagai gastropati kemikal (reaktif). ${ }^{5,7}$ Secara fisikokimia, aspirin diserap dengan cepat, terakumulasi dalam mukosa, dan menyebabkan penyekat mukosa lambung rusak. Kandungan salisilat dalam aspirin akan tertahan dalam sel epitel lambung diperantarai oleh proses yang tergantung ATPase yang mengakibatkan peningkatan permeabilitas membran sel, pembengkakan sel, dan kematian sel. ${ }^{5}$ Hilangnya penyekat mukosa menyebabkan difusi balik ion hidrogen sehingga terjadi cedera sekunder. Cedera pada permukaan mukosa lambung menyebabkan terjadinya pelepasan sel-sel epitel permukaan dan respons pembuluh darah sehingga terjadi peningkatan permeabilitas dan pelepasan mediator histamin yang menimbulkan edema dan hiperemia mukosa lambung. Cedera berulang dapat menyebabkan pelepasan agen proinflamasi seperti platelet derived growth factor (PDGF), yang merangsang proliferasi otot polos dan fibroblas. Cedera sel epitel terjadi setelah mukosa lambung terpapar dengan AINS yang disebabkan karena berkurangnya sintesis prostaglandin. Prostaglandin merupakan agen yang sangat penting karena bersifat sitoprotektif terhadap mukosa lambung, mempertahankan aliran darah mukosa melalui peningkatan sekresi mukus dan ion bikarbonat, dan meningkatkan pertahanan sel epitel terhadap cedera sitotoksik. ${ }^{7}$

Pada tikus perlakuan kelompok III yang diberikan aspirin dengan dosis yang sama selama 10 hari kemudian dihentikan dan diterminasi pada hari ke-14 ternyata infiltrasi sel radang PMN dan edema berkurang dibandingkan dengan tikus perlakuan kelompok II. Pemakaian aspirin jangka panjang lebih kurang mengakibatkan kerusakan karena mukosa lambung telah beradaptasi dan resisten terhadap aspirin. Respons adaptif ini mencakup adanya penurunan infiltrasi sel-sel radang PMN dan proliferasi sel-sel epitel yang meluas. ${ }^{5}$ Pada penelitian ini pemberian aspirin dihentikan 
pada hari ke-11 dan tikus hanya diberi pelet sampai diterminasi hari ke-14. Berkurangnya sel-sel radang dan edema disebabkan karena mukosa lambung tidak terpapar lagi dengan aspirin, dan reaksi radang pada mukosa lambung mulai mengalami resolusi; mungkin juga karena terjadinya respons adaptif seperti yang telah disebutkan di atas.

\section{SIMPULAN}

Pemberian aspirin dengan dosis 21 $\mathrm{mg} /$ hari selama 10 hari pada tikus wistar memperihatkan gambaran histopatologik suatu gastritis akut. Penghentian pemberian aspirin diikuti dengan resolusi reaksi inflamasi yang ditandai oleh penurunan infiltrasi sel-sel radang PMN dan edema jaringan.

\section{DAFTAR PUSTAKA}

1. Furst DE, Ulrich RW. Obat-obat antiinflamasi non-steroid, obat-obat antireumatik pemodifikasi-penyakit, analgesik nonopioid dan obat-obat untuk pirai. In: Nirmala WK, Yesdelita N, Susanto D, Dany F, editors. Farmakologi Dasar dan Klinik [Diterjemahkan dari: Katzung BG, editor. Basic \& Clinical Pharmacology (Tenth Edition)]. Jakarta: Penerbit Buku Kedokteran EGC, 2007; p. 589-609.

2. Kadar D. Anti-inflammatory analgesics. In: Kalant H, Grant DM, Mitchell J. Principal of Medical Pharmacology. Toronto: Elsevier, 2007; p. 364-81.

3. Wilmana FP, Gan S. Analgesik-antipiretik analgesik anti-inflamasi nonsteroid dan obat gangguan sendi lainnya. In: Gunawan SG, Setiabudy R, Nafrialdi, Elysabeth, editors. Farmakologi dan
Terapi (Edisi 5). Jakarta: Balai Penerbit FKUI, 2007; p. 230-5.

4. Zeehnder JL. Obat-obat yang digunakan pada gangguan-gangguan pembekuan darah. In: Nirmala WK, Yesdelita N, Susanto D, Dany F, editors. Farmakologi Dasar dan Klinik [Diterjemahkan dari: Katzung BG, editor. Basic \& Clinical Pharmacology (Tenth Edition)]. Jakarta: Penerbit Buku Kedokteran EGC, 2007; p. 555-74.

5. Fenoglio-Preiser CM, Noffdinger AE, Stemmermann GN, Lantz PE, Isaacson PG. Gastrointestinal Pathology An Atlas and Text (Third Edition). Philadelphia: Lippincott Williams \& Wilkins Wolter Kluwer, 2008; p.155-61.

6. Mills SA, Contos MJ, Goel R. The stomach. In: Silverberg SG, editor. Silverberg's Principles and Practice of Surgical Pathology and Cytopathology Vol. 2 (Fourth Edition). New York: Churchill Livingstone Elsevier, 2006. P. 1321-1338.

7. Genta RM. Inflammatory disorders of the stomach. In: Robert D Odze, John R Goldblum, James W Crawford, editors. Surgical Pathology of the GI Tract, Liver, Biliary Tract, Pancreas Vol. 1. Philadelphia: Saunders Elsevier, 2004; p.143-176.

8. Turner JR. The Gastrointestinal Tract. In: Kumar V, Abbas AK, Fausto N, Aster JC. Robbins and Cotran Pathologic Basis of Disease (Eight Edition). Philadelphia: Saunders Elsevier, 2010; p.774-6.

9. Rosai J. Rosai and Ackerman's Surgical Pathology Vol. 1 (Tenth Edition). Edinburgh: Elsevier Mosby, 2011.

10. Chandrasoma $P$, Taylor $C R$. Concise Pathology (Third Edition). Stamford Connecticut: Appleton \& Lange, 1998. 